\title{
Research on Degradation Characteristics of Nonylphenol in Water by Highly Effective Complex Microorganisms
}

\author{
Juan Ma, Fang-yan Chen*, Yu-bin Tang, and Xin-gang Wang \\ School of Environmental and Chemical Engineering, Jiangsu University of Science and Technology, Zhenjiang 212018, Jiangsu, China
}

\begin{abstract}
Aiming at effectively controlling nonylphenol (NP) pollution, three bacterial strains were isolated from activated sludge and landfill leachate, which could grow with nonylphenol as sole carbon and energy source. The three nonylphenol-degrading bacteria isolated were named as WN6, SLY9 and SLY10, respectively. The morphological observation and $16 \mathrm{~S}$ rDNA identification revealed that the strains belonged to Serratia sp., Klebsiella sp. and Pseudomonas putida, respectively. WN6 and SLY9 contained ALK gene, while WN6 and SLY10 harbored C12O genes. The three strains were combined together to form complex microorganisms ZJF. The ratio of Serratia sp. to Klebsiella sp. to Pseudomonas putida was 2:1:2 (volume ratio of bacterial suspension). Under the conditions that temperature was $30{ }^{\circ} \mathrm{C}, \mathrm{pH}$ was 6 , inoculation amount was $10 \%$ (volume ratio), initial concentration of NP solutions was $20 \mathrm{mg} / \mathrm{L}$, NP degradation rate by ZJF reached $73.82 \%$, compared with any single strain of the three bacteria, NP degradation rate by ZJF increased more than $15 \%$ during 6 days. Bioremediation of nonylphenol-polluted the Yangtze River and the Ancient Canal water by ZJF ware simulated. After a 6-day incubation period, the degrading rate of nonylphenol in Ancient Canal water was close to $80 \%$, and the degrading rate of nonylphenol in Yangtze River water was $72.84 \%$.
\end{abstract}

\section{Introduction}

Nonylphenol (NP) in environments is often a product of the microbial breakdown of nonylphenol ethoxylates (NPEOs). NPEOs, as an important group of non-ionic surfactants, is often found in waste liquids discharged from a variety of industrial cleaning, textile dyeing, paper making and leather chemicals. NPEOs can be partially biodegraded, and the product NP is reported to be more persistent and toxic than the parent compounds, when they are directly released to aquatic environments [1]. Another source of NP emissions is industrial wastewater which often contains NP, resulting in an increase in environment NP content [2]. Previous study showed that NP belonged to the group of environmental hormones, a class of endocrine disrupters that can mimic the effects of estrogenic compounds and disturb the hormonal system. Hence, NP has been shown to stimulate or suppress the immune system [3].

Compared to the chemical treatments, microbial treatment offers advantages such as low cost, low energy, little dependence of chemicals, and mild environmental conditions. Therefore, microbial reactions with the potential to reduce NP have received increasing attention. The microorganisms to degrade NP varies with the environment for NP existence, the NP-degrading microorganisms mainly include bacteria, fungi and algae [1]. To this day, many NP-degrading bacterial species, mainly belonging to genera Pseudomonas, Sphingobium and Sphingomonas, have been isolated from various environments [4-5].

At present, in most cases, people are apt to use single cultures to degrade NP in environment. When using the single species isolated, although it is usually the dominant bacteria, it is difficult to realize industrialization due to their being eliminated by the bacteria in environment. However, the complex microorganisms can compensate for this deficiency from single cultures. At present, the research on NP degradation by complex microorganisms is only a little in China and the other country. In this research, NP-degrading bacteria were isolated to build efficient NP-degrading complex microorganisms. The degradation characteristic of the complex microorganisms was studied to provide a reference for the biological treatment of NP-containing wastewater and the bioremediation of NP-polluted water.

\section{Materials and methods}

\subsection{Chemicals and medium}

* Corresponding author: catchen1029@sohu.com 


\subsubsection{NP-ethanol reserving solution}

Nonylphenol (> 99\% purity, with linear chain) and ethanol (> 99\% purity) were purchased from Aladdin (Shanghai, China). The NP-ethanol reserving solution (the concentration of NP solution was $0.05 \mathrm{~g} / \mathrm{mL}$ ) was prepared by the following method: $0.5 \mathrm{~g} \mathrm{NP}$ was accurately weighted and dissolved in ethanol, then metered volume in $100 \mathrm{~mL}$ Brown volumetric flask, and stored at $4^{\circ} \mathrm{C}$.

\subsubsection{NA medium}

Beef extract, peptone and agar were purchased from Beijing Aobox Biotechnology Co., ltd., $\mathrm{NaCl}$ (99.7\% purity) purchased from Aladdin (Shanghai, China).

Preparation of NA medium: Beef extract $10 \mathrm{~g}$, peptone $20 \mathrm{~g}, \mathrm{NaCl} 10 \mathrm{~g}$, agar powder $18 \mathrm{~g}$, distilled water 1000 $\mathrm{mL}$, the value of $\mathrm{pH}$ was adjusted to be 7.0 7.2, and the medium was autoclaved at $121^{\circ} \mathrm{C}$ for $20 \mathrm{~min}$.

\subsubsection{Inorganic salt medium}

All of $\mathrm{NH}_{4} \mathrm{Cl}, \quad \mathrm{KH}_{2} \mathrm{PO}_{4}, \mathrm{Na}_{2} \mathrm{HPO}_{4}, \mathrm{MgSO}_{4} \cdot 7 \mathrm{H}_{2} \mathrm{O}$, $\mathrm{FeSO}_{4} \cdot 7 \mathrm{H}_{2} \mathrm{O}, \mathrm{MnCl}_{2} \cdot 4 \mathrm{H}_{2} \mathrm{O}$ and $\mathrm{CaCl}_{2} \cdot 2 \mathrm{H}_{2} \mathrm{O}$, with $99.7 \%$ purity, were purchased from Aladdin (Shanghai, China).

Preparation of inorganic salt medium: $\mathrm{NH}_{4} \mathrm{Cl} 2.5 \mathrm{~g}$, $\mathrm{KH}_{2} \mathrm{PO}_{4} 2.5 \mathrm{~g}, \mathrm{Na}_{2} \mathrm{HPO}_{4} 5 \mathrm{~g}, \mathrm{MgSO}_{4} \cdot 7 \mathrm{H}_{2} \mathrm{O} 0.5 \mathrm{~g}$, $\mathrm{FeSO}_{4} \cdot 7 \mathrm{H}_{2} \mathrm{O} 0.05 \mathrm{~g}, \mathrm{MnCl}_{2} \cdot 4 \mathrm{H}_{2} \mathrm{O} 0.2 \mathrm{~g}, \mathrm{CaCl}_{2} \cdot 2 \mathrm{H}_{2} \mathrm{O}$ $0.05 \mathrm{~g}$, distilled water $1000 \mathrm{~mL}$, the value of $\mathrm{pH}$ was adjusted to be 7.0 7.2, and the medium was autoclaved at $121^{\circ} \mathrm{C}$ for $20 \mathrm{~min}$.

\subsubsection{Inorganic salt solid medium}

$2 \%$ agar powder (volume fraction) was added into the prepared inorganic salt medium mentioned above; the inorganic salt solid medium was formed.

\subsection{Isolation and purification of NP-degrading bacteria}

Bacteria sources were obtained from activated sludge at Jingkou district wastewater treatment plant and the landfill leachate from Zhengzhou garbage landfill disposal plant. $10 \mathrm{~mL}$ of the activated sludge or landfill leachate was added to $90 \mathrm{~mL}$ NP-containing medium in a $250 \mathrm{~mL}$ flask (pH 7.0) (I.e. $100 \mathrm{~mL}$ culture solution contains $10 \mathrm{~mL}$ activated sludge or landfill leachate). Moreover, stepwise domestication method was used, domestication was treated with different concentration gradient of NP (1 $\mathrm{mg} / \mathrm{L}, 5 \mathrm{mg} / \mathrm{L}, 10 \mathrm{mg} / \mathrm{L}, 20 \mathrm{mg} / \mathrm{L}, 30 \mathrm{mg} / \mathrm{L}, 50 \mathrm{mg} / \mathrm{L}, 80$ $\mathrm{mg} / \mathrm{L}, 100 \mathrm{mg} / \mathrm{L}, 150 \mathrm{mg} / \mathrm{L}, 200 \mathrm{mg} / \mathrm{L}$ ) for screening and isolation of dominant microbe. The flasks were incubated at $30^{\circ} \mathrm{C}$ on a shaker in the dark at $120 \mathrm{rpm}$. Each gradient were incubated for 5 days. Inoculated culture repeatedly, then isolated, purified, until a pure single colony was obtained. The obtained strains were inoculated onto the inorganic salt plate sprayed with NP stock solution. After 5 days of incubation at $30^{\circ} \mathrm{C}$, colonies showing evidence of NP degradation were picked and then streaked repeatedly (three times) for purity. Isolated colonies were picked, and stored at $-80^{\circ} \mathrm{C}$.

\subsection{Identification of NP-degrading isolates and degradation genes}

Identification of strains was determined through $16 \mathrm{~S}$ rDNA sequence homology analysis. Total chromosomal DNA from the three isolates was extracted by Rapid Bacterial Genomic DNA Isolation Kit from Sangon Biotech. Two oligonucleotides (27f: AGAGTTTGATCCTGGCTCAG and 1492r: TACCTTGTTACGACTT) were used for polymerase chain reaction (PCR) to amplify $16 \mathrm{~S}$ rDNA. PCR was conducted as follow ( $25 \mu \mathrm{L}$ PCR reaction system): $1.0 \mu \mathrm{L}$ of 10 pmole each primer, $1 \mu \mathrm{L}(10 \mathrm{ng} / \mu \mathrm{L})$ DNA template, $0.25 \mu \mathrm{L}$ Taq polymerase $(2.5 \mathrm{U} / \mu \mathrm{L}), 2.5 \mu \mathrm{L}$ of $10 \times \mathrm{DNA}$ Taq polymerase buffer, $2.0 \mu \mathrm{L}$ of $10 \mathrm{mM}$ dNTP, and 17.25 $\mu \mathrm{L}$ of $\mathrm{ddH}_{2} \mathrm{O}$. PCR was conducted for 35 cycles, with initial denaturation at $94^{\circ} \mathrm{C}$ for $5 \mathrm{~min}$, denaturation at $94^{\circ} \mathrm{C}$ for $45 \mathrm{~s}$, annealing at $55^{\circ} \mathrm{C}$ for $45 \mathrm{~s}$, and extension at $72^{\circ} \mathrm{C}$ for $90 \mathrm{~s}$, followed by a final extension at $72^{\circ} \mathrm{C}$ for $10 \mathrm{~min}$ using the Program Temp Control System ABI-Veriti. The PCR products $(10 \mu \mathrm{L})$ were analyzed by electrophoresis on a $1.0 \%$ agarose gel stained with $0.5 \mathrm{~g} / \mathrm{mL}$ of ethidium bromide solution. The PCR products were cloned into pMD18-Tvector, and then were transformed into competent cell of DH10B. The 16S rDNA sequences were sequenced by Sangon Biotech. Homology searches of sequences were conducted using a ribosomal database. Phylogenetic tree was constructed using MEGA 5.0 software.

The alkaline hydroxylase (ALK), catechol 1, 2dioxygenase (C12O), catechol 2, 3-dioxygenase (C23O) genes were amplified according to the literature $[6,7]$.

\subsection{Construction of Complex microorganisms}

Three inocula were separately prepared by inoculating the three activated strains into the NA medium. Each bacterium was cultured till logarithmic growth phase at $30^{\circ} \mathrm{C}$ on a shaker in the dark at $140 \mathrm{rpm}$. These activated cells were harvested as inocula after $24 \mathrm{~h}$, respectively. The cells were collected by centrifugation $(4,000 \mathrm{rpm}$ for 10 $\mathrm{min}$ ) and cleaned with phosphate buffer saline. They were suspended in the phosphate buffer saline and the bacterial suspension with an initial optical density (OD 600) of 1.0 was prepared. A fixed, known volume of inorganic salt culture medium $(25 \mathrm{~mL})$ was added into each of a series of conical flasks (100 mL capacity) and some volume of nonylphenol stock solution added to each flask so that the concentration of nonylphenol solution in each flask reach $20 \mathrm{mg} / \mathrm{L}$. The bacterial suspension of a single species of WN6, SLY9 or SLY10, or a compound species (Volume proportion of bacterial suspension are shown in Table 1) was inoculated into the inorganic salt medium containing $20 \mathrm{mg} / \mathrm{L}$ of nonylphenol mentioned as above, as per $10 \%$ of inoculation quantity ( $25 \mathrm{~mL}$ of culture solution contains $2.5 \mathrm{~mL}$ of bacterial suspension). The cultures were then incubated on a rotary shaker $(120 \mathrm{rpm})$ at $30^{\circ} \mathrm{C}$. Samples for biodegradation studies and detection of $\mathrm{OD}$ value were 
collected every $24 \mathrm{~h}$ up to $72 \mathrm{~h}$ of culturing. Flasks containing NP without cultures addition acted as blank control groups. Every culture time point was prepared and analyzed in triplicate.

\subsection{Extraction and quantitative detection of NP}

The residual NP in culture medium was extracted as previously described [4]. The mixture was filtered with a $0.45 \mathrm{~mm}$ syringe filter and the filtrate was analyzed with high performance liquid chromatography (Shimadzu, LC20A) ( $\left.r^{2}>0.999\right)$. Chromatography separation was conducted on a Inertsil ODS-SP C18, the detection wavelength was $276 \mathrm{~nm}$, column temperature was $35^{\circ} \mathrm{C}$, the injection volume $10 \mu \mathrm{L}$, using methanol-water (90:10) as the mobile phase at a flow rate of $1 \mathrm{~mL} / \mathrm{min}$.

\subsection{Growth and Biodegradation Condition Optimization of ZJF}

The following factors were manipulated to investigate their effects on NP biodegradation: the initial concentrations of $\mathrm{NP}(5,10,15,20,30,40,50,60,70,80$, $100 \mathrm{mg} / \mathrm{L}) ; \mathrm{pH}(4.0,5.0,6.0,7.0,8.0,9.0$ or 10.0$)$; temperature $\left(20,25,30,35,40\right.$ or $\left.45^{\circ} \mathrm{C}\right)$. Unless otherwise noted, sample bottles containing $25 \mathrm{~mL}$ of inorganic salt solid medium, NP at concentrations of $20 \mathrm{mg} / \mathrm{L}$, they were incubated at $30^{\circ} \mathrm{C}$ on a shaker at $120 \mathrm{rpm}, \mathrm{pH} 7.0$ and inoculation amount was $10 \%$ in the dark for 3 days. Aqueous samples were periodically collected in order to measure OD value and residual NP concentrations. Every culture time point was prepared and analyzed in triplicate.

\subsection{Simulated bioremediation of NP-polluted water of the Yangtze River and the Ancient Canal by ZJF}

Taken $25 \mathrm{~mL}$ the Yangtze River or the Ancient Canal water into Erlenmeyer flask $(\mathrm{V}=100 \mathrm{~mL})$ and added 20 $\mathrm{mg} / \mathrm{L} \mathrm{NP}$ addition (stock solution $50 \mathrm{mg} / \mathrm{mL}$ in ethanol), which simulated the NP-polluted Yangtze River water and the Ancient Canal water. The water quality of the Yangtze River of Zhenjiang: TN $1.68 \mathrm{mg} / \mathrm{L}$, TP $0.362 \mathrm{mg} / \mathrm{L}$, COD $19.5 \mathrm{mg} / \mathrm{L}$, pH 7.5.The water quality of the Ancient Canal of Zhenjiang: TN $1.92 \mathrm{mg} / \mathrm{L}$, TP $0.31 \mathrm{mg} / \mathrm{L}$, COD 28.7 $\mathrm{mg} / \mathrm{L}, \mathrm{pH}$ 7.1. The inoculum of ZJF (10\%) (Activated 12 $\mathrm{h}, \mathrm{OD}_{600}=1.0$ ) was then transferred into Erlenmeyer flasks $(\mathrm{V}=100 \mathrm{~mL})$. Cultures were then incubated on a rotary shaker $(120 \mathrm{rpm})$ at $30^{\circ} \mathrm{C}$. Samples for biodegradation studies were collected every $24 \mathrm{~h}$ up to $144 \mathrm{~h}$ of culturing. The experiment was divided into two groups: (1) It only uses indigenous microorganisms from the Yangtze River water and Ancient Canal water for simulating restoration of the NP-polluted Yangtze River water and the Ancient Canal water and did not add microbial consortium ZJF.(2) By adding microbial consortium ZJF into the Yangtze River water and the Ancient Canal water to investigate the effect of simulating bioremediation of NP-polluted the Yangtze River water by microbial consortium ZJF and indigenous microorganisms from the Yangtze River and the Ancient Canal.

\section{Results and Discussion}

\subsection{Characterization of the NP-degrading isolates and genes}

\subsubsection{Identification of strains}

Three bacterial strains were isolated from the activated sludge and the landfill leachate. They could grow with NP as sole carbon and energy source. The three NP-degrading bacteria were named as WN6, SLY9 and SLY10, respectively. The morphology observation revealed that strain WN6 was a fine and tarnish bacterium which appear yellow colonies on NA media. The strain SLY9 was a big and flat colony with white color on NA media. The strain SLY10 was a round colony with milkiness color on NA media. Gram staining reaction of the three bacterial strains was negative.

The phylogenetic tree of the strains based on $16 \mathrm{~S}$ rDNA gene homology is shown in Fig. 1. 


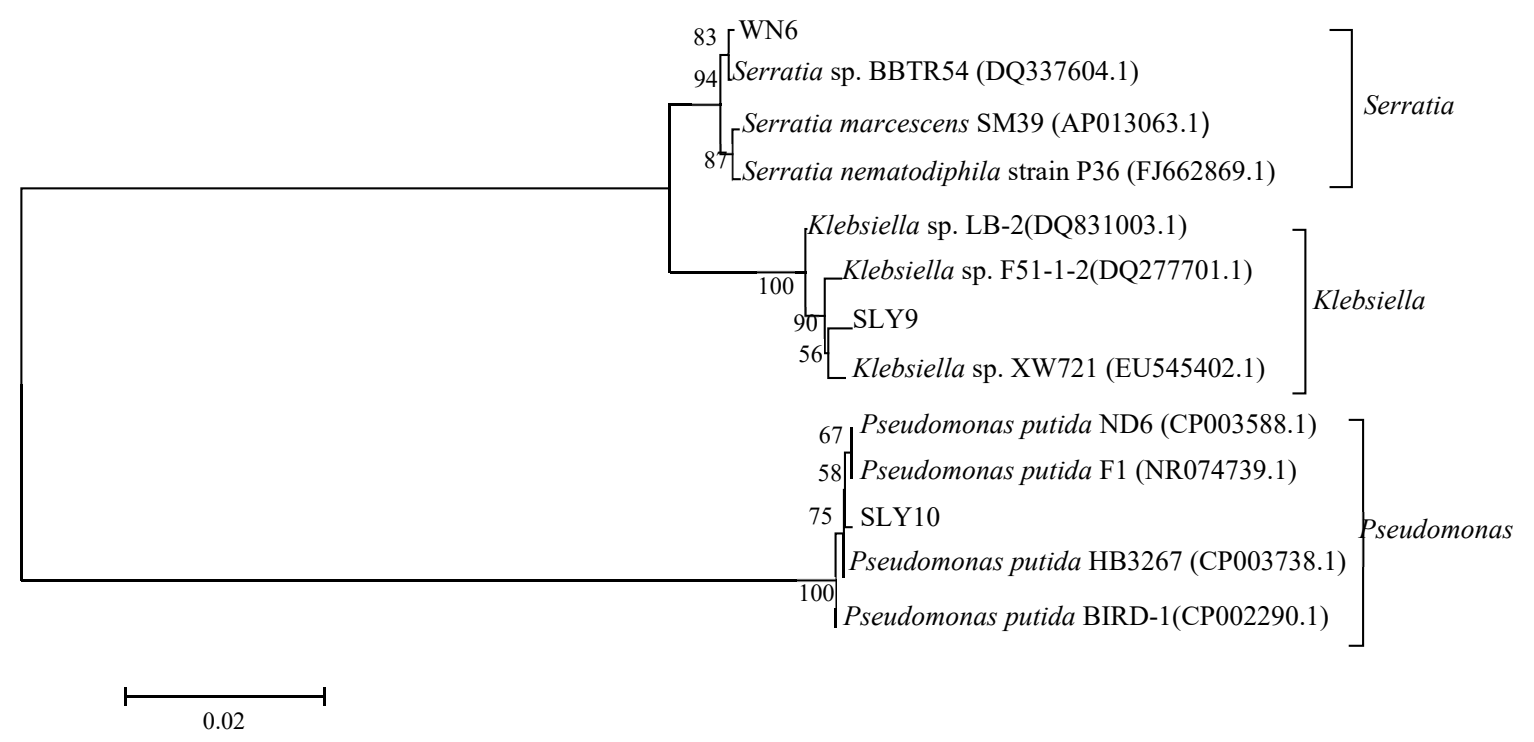

Fig. 1. The phylogenetic tree of strains based on 16S rDNA gene homology

The result revealed that strain WN6, SLY9, Serratia sp. and Klebsiella sp. formed one cluster, respectively, which implied that they were closely related. The strain WN6 and SLY9 could be assigned to Serratia sp. and Klebsiella sp. Genus, respectively, within class enterobacteriaceae based on the DNA sequence data and its morphology. However, the strain SLY10 and cyanide putida formed one cluster, which implied that they were closely related, therefore, it was Pseudomonas putida within genus pseudomonas.

Klebsiella sp. Serratia sp. and Pseudomonas putida had application value in agricultural field and environmental management. They participated in

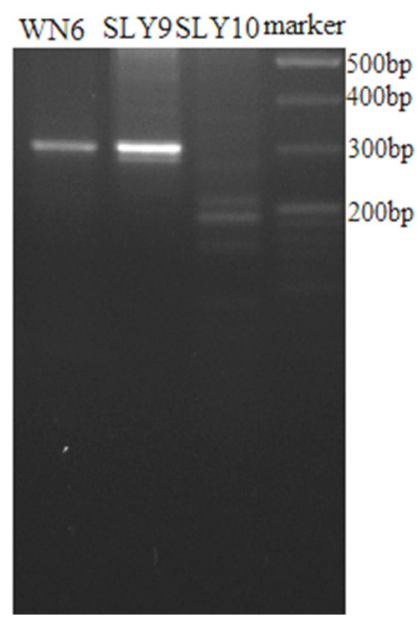

A biodegradation of aromatic compounds [8-10], carbazole [11], cyanide [12] and multiple contaminants and improving plant utilization of nitrogen, phosphorus, iron and other nutrients [13]. This is the first study showing that Klebsiella sp. can degrade NP. However, Serratia sp. and Pseudomonas putida have been reported to bioremediate NP pollution $[14,15]$.

\subsubsection{Identification of degradative genes}

The PCR product electrophorogram of the degrading genes of the three strains was shown in Fig. 2.

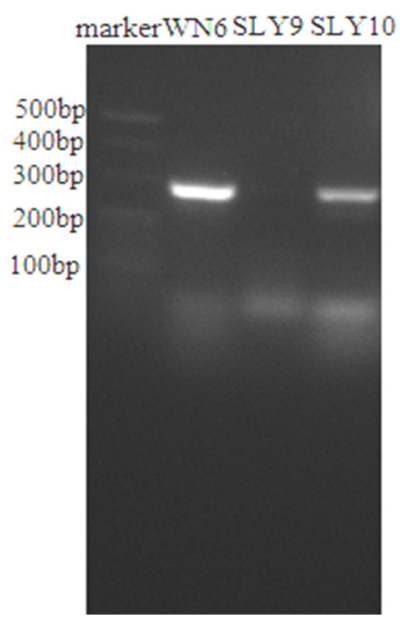

B

Fig. 2. A: PCR amplification of the $A L K$ genes from three isolated strains with ALK primers B: PCR amplification of the $C 12 O$ genes from three isolated strains with $\mathrm{C} 12 \mathrm{O}$ primers

Fig. 2A shows the $A L K$ genes (ALK primers) could amplify specific DNA fragments from strains WN6 and SLY9, the sizes of DNA fragments were $330 \mathrm{bp}$. The results revealed that strains WN6 and SLY9 contained $A L K$ gene according to the literature [6]. Fig. 2B shows the C12O genes (C12O primers) could amplify specific DNA fragments from strains WN6 and SLY10, the sizes of DNA fragments were $280 \mathrm{bp}$. According to the literature
[7], the strains WN6 and SLY9 contained C12O gene. Zhao Wang (2014) also identified the Rhizobium contained $A L K$ gene, while the Sphingobium harbored $A L K$ and $C 23 O$ genes.

Previous studies on biodegradation of alkyl phenols have revealed that short-chain and/or medium-chain alkyl phenols can be degraded by a number of different strains that mostly belong to the genus Pseudomonas [16]. In the 
degradation process, catechol is an important intermediate product. Benzene rings of catechol were broken by either catechol 1, 2-dioxygenase (C12O), the ortho-pathway, or catechol 2, 3-dioxygenase (C23O), the meta-pathway [17]. $\mathrm{C} 12 \mathrm{O}$ and $\mathrm{C} 23 \mathrm{O}$ genes have been accepted as two key metabolic genes in degradation of aromatic compounds. Munehiro Nishimura et al. (2007) [18] also suggested this pathway for biodegradation of butyl phenol by Pseudomonas putida. In present study, C12O gene was detected in strain WN6 and SLY10 revealed that the two strains might degrade NP via phenolic ring cleavage. In addition, $\mathrm{C} 12 \mathrm{O}$ genes in strain SLY9 was not detected, suggested that this stain could not degrade NP via phenolic ring cleavage.

Alkane catabolic genes are known for encoding key enzyme responsible for the first step in aerobic oxidation of alkane compounds. Some representative achievements are alkane hydroxylase systems from Pseudomonas oleovorans GPo1 [16]. The membrane-bound alkane hydroxylase need rubredoxin and rubredoxin reductase to transfer electron in catalyzing alkanes via a terminal oxidation pathway with alkane hydroxylase. In this research, ALK gene was detected in strains WN6 and SLY9 suggested that the strains might degrade NP via a terminal oxidation pathway with alkane hydroxylase.

However, the detection of functional genes did not necessarily mean that these genes were truly responsible for the biodegradation of NP. Proteomics might be an alternative to identify NP degradation pathway [4].

\subsection{Biodegradability of nonylphenol by the different kinds of microorganisms}

Biodegradability of NP (the initial concentration was 20 $\mathrm{mg} / \mathrm{L}$ ) by the single strain isolated and the composite strains is shown in Table 1.

Table 1 revealed that under same conditions, when initial concentration of NP solutions was $20 \mathrm{mg} / \mathrm{L}$, the degradation efficiency of NP (Deducted blank control

Table 1. Biodegradability of nonylphenol by various combinations of microorganisms

\begin{tabular}{|c|c||c|c|}
\hline Single strain & Degradation rates (\%) & Complex microorganisms & Degradation rates (\%) \\
\hline WN6 & 58.22 & WN6:SLY9:SLY10=1:1:1 & 72.43 \\
\hline SLY9 & 51.64 & WN6:SLY9:SLY10=2:1:2 & 73.82 \\
\hline SLY10 & 50.19 & WN6:SLY9:SLY10=1:2:2 & 61.39 \\
\hline- & - & WN6:SLY9:SLY10=2:2:1 & 57.76 \\
\hline
\end{tabular}

group) by WN6, SLY9 and SLY 10 is $58.22 \%, 51.64 \%$ and $50.19 \%$, respectively. However, the degradation efficiency was increased to $57 \% \sim 73 \%$ when using the flora composed by the three strains at a certain proportion. The degradation efficiency by the microbial population composed according to the ratio of WN6:SLY9:SLY10=2:1:2 (volume ratio) was the highest, reached $73.82 \%$, which is $15 \%$ higher than that by any single strain among the three strains. This is because the three isolated strains can increase resistance to toxicity of NP through using each different degradation pathways, under co-substrate and communal synergistic metabolism. In order to get the best biodegradability, this compound microorganisms (named as ZJF) was prepared for the after experiment.

Wu Wei [19] indicates that the compound strains have been used to reduce the pollution caused by the nonylphenol ethoxylates in the sewage. The ratio of Bacillus sp. to Pseudomonas sp. to Norcardia sp. to Candida sp. in the compound strains was $1: 2: 1: 1$. The actual degradation rate of nonylphenol ethoxylates by the compound strains proves to be able to reach $61 \%$, which is $16 \%$ higher than that by the most efficient single strain.

\subsection{Effect of initial concentration of NP on the degradation efficiencies by ZJF}

The effect of initial concentration of NP on NP degradation efficiencies is shown in Fig. 3.

As shown in Fig. 3, the optimal initial concentration of NP solutions for WN6, SLY9 and SLY10 was $15 \mathrm{mg} / \mathrm{L}, 10$ $\mathrm{mg} / \mathrm{L}$ and $15 \mathrm{mg} / \mathrm{L}$, respectively. The degradation efficiencies were all above $60 \%$. Thereafter, as increasing of NP concentration, the degradation activity was inhibited, the degradation rate decreased gradually. When NP concentration was higher than $60 \mathrm{mg} / \mathrm{L}$, the degradation rate by every single strain decreased to less than $30 \%$. However, the highest degrading rate reached $73.82 \%$ when the initial concentration of NP solutions was $20 \mathrm{mg} / \mathrm{L}$. The

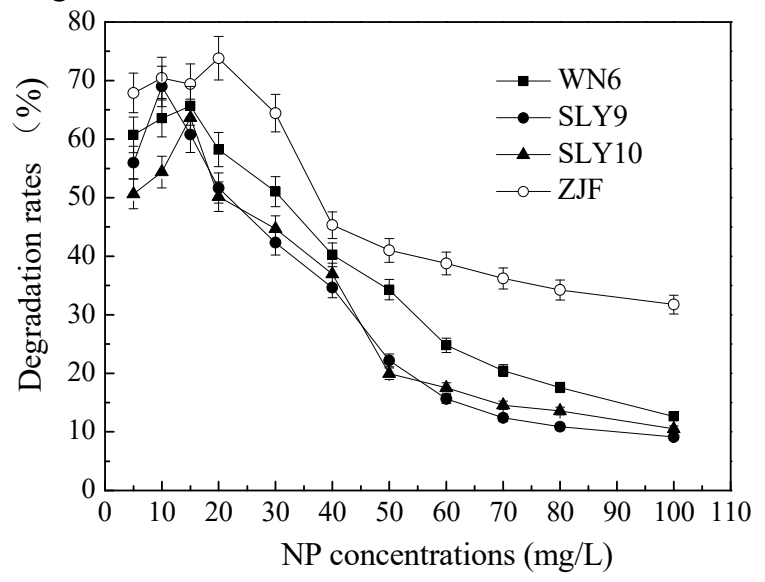

Fig. 3. Effect of initial NP concentration on degradation efficiencies of ZJF 
degradation rate was $15.6 \%$ higher than that by the single strain. Especially, the degradation rate of NP by ZJF still reached $31.74 \%$ when the initial concentration of NP increased to $100 \mathrm{mg} / \mathrm{L}$. The results show that the ZJF had better tolerance and metabolic capability to NP than single cultures and it can be used for biological treatment of NP wastewater with higher concentration.

\subsection{Effect of pH on NP biodegradation and growth of composite microorganisms groups ZJF}

The effect of $\mathrm{pH}$ on degradation of NP and growth of ZJF are shown in Fig. 4.

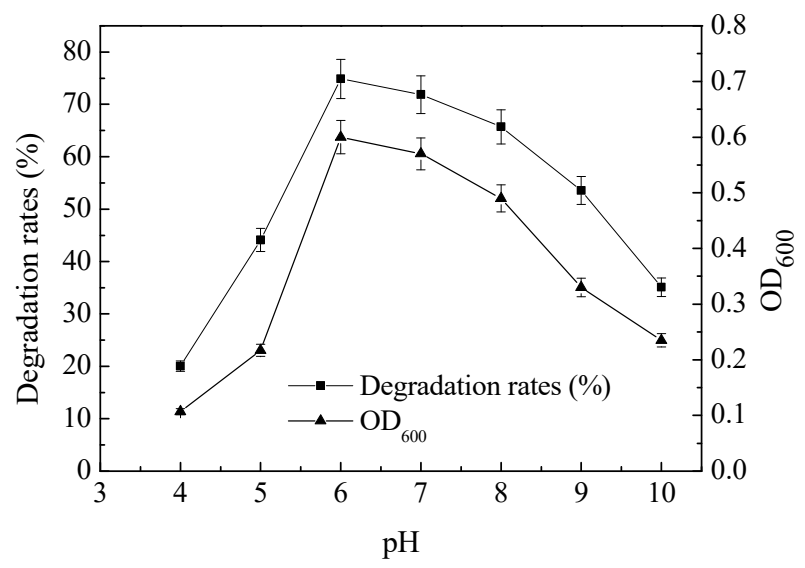

Fig. 4. Effect of $\mathrm{pH}$ on NP biodegradation and growth of ZJF

From Fig. 4 we can see that when $\mathrm{pH}$ was lower than 6.0 , the cell growth $\left(\mathrm{OD}_{600}\right)$ and the degradation rate of $\mathrm{NP}$ increase with the rise of $\mathrm{pH}$. It was found that, when $\mathrm{pH}$ was more than 6.0, as increasing of $\mathrm{pH}$, the cell growth and the degradation activity was inhibited. The results showed that the cell growth and the degradation activity were easily inhibited when the $\mathrm{pH}$ value was too high or too low. The experimental data indicated that the growth of ZJF was the most exuberant and the highest degrading rate of NP reached $74.23 \%$ at $\mathrm{pH} 6.0$ in the medium. Therefore the optimal $\mathrm{pH}$ value for NP biodegradation was determined to be 6.0 .

\subsection{Effect of temperature on NP biodegradation and growth of composite microorganisms groups ZJF}

The effect of temperature on degradation of NP and growth of ZJF are shown in Fig. 5.

The Fig. 5 showed that the composite microorganisms groups ZJF had good degradation ability for NP, the degradation rate of NP reached over $50 \%$ under the conditions of $25^{\circ} \mathrm{C} \sim 40^{\circ} \mathrm{C}$. As can be seen, range of suitable temperature of composite microorganisms groups ZJF was wide. Nevertheless, the results showed that the cell growth and the degradation activity were easily inhibited when the reaction temperature was too low or too high. This is because the degradation enzyme activity was relatively lower when temperature was too low. And, too high temperature can result in inactivation of enzyme, and then inhibit biodegradation ability of ZJF. Only when temperature was at $30^{\circ} \mathrm{C}$, the parameter $\mathrm{OD}_{600}$ which express growth quantity of the bacterial community ZJF reached the maximum value, and, at this point, the degrading rate of NP is the highest, reached to $73.82 \%$, indicated that the activity of NP-degrading enzyme excreted by ZJF is the highest and the metabolism ability is the strongest, when the temperature is at $30^{\circ} \mathrm{C}$. Hence, $30^{\circ} \mathrm{C}$ was chosen as the optimal temperature for $\mathrm{NP}$ biodegradation.

Some researchers $[19,20]$ found that the degrading rate of NP was higher in the temperature range of $25^{\circ} \mathrm{C} \sim 35^{\circ} \mathrm{C}$, in this temperature range, the NP-degrading bacteria grew vigorously, and the degradation enzyme activity is also higher.

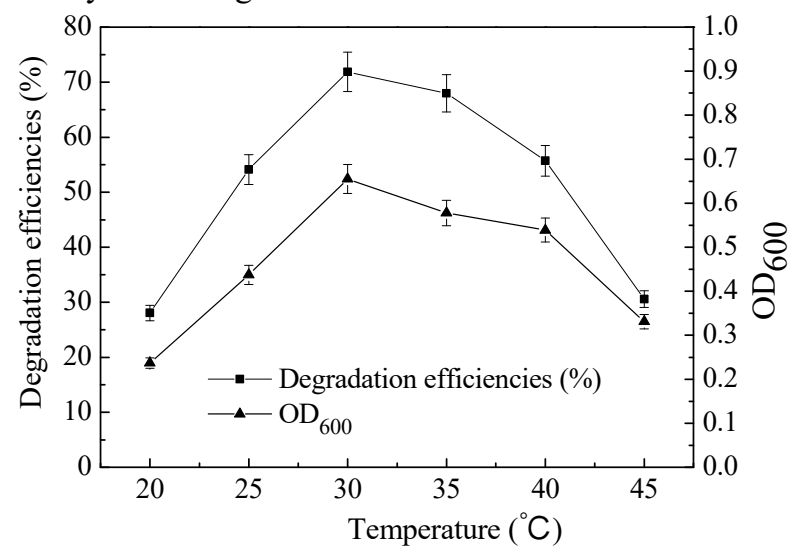

Fig. 5. Effect of temperature on NP biodegradation and growth of ZJF

\subsection{Simulated bioremediation of NP-polluted water of the Yangtze River and the Ancient Canal by ZJF}

The results of simulated bioremediation of NP-polluted waters from the Yangtze River and the Ancient Canal by ZJF are shown in Fig. 6.

Form Fig. 6 we can see that the indigenous microorganisms showed a certain ability to restore NPpolluted river water; this might be the result of induction of NP to the indigenous microbial enzyme system. The indigenous microorganisms in the Ancient Canal, however, were more adaptive to NP than those in the Yangtze River. This is because that the Ancient Canal gone through the urban field, so that the canal water was heavily polluted by domestic wastewater, the number and species of microorganisms in the canal water were more than that in The Yangtse River, canal waters maybe contains more NP-degrading bacteria. But even NP-degrading bacteria exist, its degradation ability for NP is not strong, because the adaptation period is relatively long in the degradation process and the degradation efficiency is relatively low. Fig. 6 showed that ZJF could coexist possibly with indigenous microorganism; it could effectively remove NP from the NP-polluted Yangtze River water and the Ancient Canal water. After a 6-day incubation period, the degradation efficiency of NP in the NP-polluted Ancient Canal water was close to $80 \%$, and for the NP-polluted Yangtze River water, the degradation efficiency was $72.84 \%$. The data indicates that the bioremediation ability of the flora ZJF for the NP-polluted Ancient Canal water was stronger than that for the NP-polluted Yangtze River 
water. This indicates that there exist NP-degrading indigenous microorganisms in the Ancient Canal water. Thus, ZJF can effectively restore NP-polluted waters, it has a certain application potential.

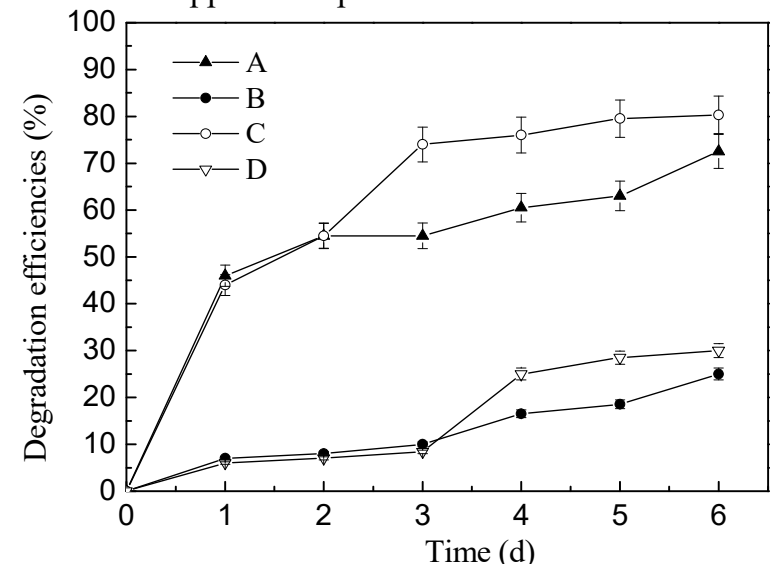

Fig. 6. A: Simulated restoration of the NP-polluted the Yangtze River water by microbial consortium ZJF and indigenous microorganisms of the Yangtze river; B: Simulated Restoration of the NP-polluted Yangtze River water by indigenous microorganisms; C: Simulated restoration of the NP-polluted Ancient Canal water by microbial consortium ZJF and indigenous microorganisms of the Ancient Canal; D: Simulated restoration of the NP-polluted Ancient Canal water by indigenous microorganisms.

\section{Conclusions}

Three NP-degrading strains were isolated and screened from activated sludge of sewage treatment plant and the landfill leachate. They were designated WN6, SLY9 and SLY10 and were identified as Serratia sp., Klebsiella sp. and Pseudomonas putida, respectively. The strains WN6 and SLY9 contained ALK gene, while strains WN6 and SLY10 harbored $\mathrm{C} 12 \mathrm{O}$ genes. The bacteria flora ZJF composed by the three strains had a strong degradation ability to NP in river water. The result of simulative bioremediation of NP-polluted Yangtze River and the ancient canal water by ZJF was satisfactory, which indicates that ZJF has potential application value in bioremediation of NP-polluted waters.

\section{Acknowledgment}

The work presented in this article was supported by the natural science foundation of Jiangsu province, China (BK2012272).

\section{References}

1 H. Z. Wu, S. Z. Liang, C. H. Wei, Environ. Prot. Chem. Ind. 26, 31 (2006)

2 X. G. Li, Y. Y. Ma, D. H. Zhang, Periodical Ocean Univ. China 43, 64(2013)

3 M. Y. Xie, X. Z. Liu, Y. J. Chen, J. Food Sci. Technol. 32, 1 (2014)

4 Z. Wang, Y. Yang, W. Sun, S. Xie, Int. Biodeterior. Biodegrad. 92, 1(2014)
5 T. Toyama, M. Murashita, K. Kobayashi, S. Kikuchi, K. Sei, Y. Tanaka , M. Ike, K. Mori, Environ. Sci. Technol. 45, 6524(2011)

6 T. Kohno, Y. Sugimoto, K. Sei, K. Mori, Microbes Environ. 17, 114(2002)

7 K. Sei, K. I. Asano, N. Tateishi, K. Mori, M. Ike, M. Fujita, J. Biosci. Bioeng. 88, 542(1999)

8 H. Z. Wu, C. H. Wei, Y. Q. Wang, Q. C. He, S. Z. Liang, J. Environ. Sci. 21, 89 (2009)

9 C. Y. Tang, W. Li, Q. X. Ye, Y. Li, Chin. J. Environ. Eng. 5, 2364(2011)

10 C. R. Wang, Z. F. Gao, J. B. Wang, F. L. Cheng, S. Chang, Environ. Pollut. Control. 35,6 (2013)

11 Y. G. Yu, K. C. Loh, Water Res.36, 1794( 2002)

12 D.Wibberg, V. M. Luque-Almagro, M. I. Igeño, A. Bremges, M. D. Roldán, F. Merchán, L. P. Sáez, M. I. Guijo, M. I. Manso, D. Macías, P. Cabello, G. Becerra, M. I. Ibáez, M. I. Carmona, M. M. P. Escribano, F.Castillo, A. Sczyrba, C. Moreno-Vivián, R. Blasco, A. Pühler, A. Schlüter, J. Biotechnol. 175, 67(2014)

13 M. J. Li, S. Peng, S. Z. Xu, D. H. Yu, M. F. Zhao, G. S. Wen, Curr. Biotechnol. 4, 415(2014)

14 X. X. Zhao, J. T. Dong, H. S. Zhuang, J. Saf. Environ. 8, 85(2008)

15 W. G. Deng, J. Y. Chen, X. M. Li, R. X. Huang, Q. Yang, K. Luo, X. Yi, Acta Scien. Circum. 33, 700(2013)

16 N. N. Tuan, H. C. Hsieh, Y. W. Lin, S. L. Huang, Bioresour. Technol. 102, 4232(2011)

17 X. M. Zhou, J. J. Chen, L. Z. Geng, D. H. Li, M. Chen, M. Lin, Biotechnol. Bull. 4, 51(2007)

18 M.Takeo, M.Nishimura, H.Takahashi, C.Kitamura, D.I. Kato, S. Negoro, J. Biosci. Bioeng.104 309(2007)

19 W. Wu, J. H. Qu, J. Z. Chen, G. D. Hu, J. Safe Environ. 3, 17(2003)

20 J. B. van Beilen, S. Panke, S. Lucchini, A. G. Franchini, M. Röthlisberger, B. Witholt, Microbiol. 147, 1621(2001) 